\title{
Classification of Citrobacteria by DNA Hybridization: Designation of Citrobacter farmeri sp. nov., Citrobacter youngae sp. nov., Citrobacter braakii sp. nov., Citrobacter werkmanii sp. nov., Citrobacter sedlakii sp. nov., and Three Unnamed Citrobacter Genomospecies
}

\author{
DON J. BRENNER, ${ }^{1 *}$ PATRICK A. D. GRIMONT, ${ }^{2}$ ARNOLD G. STEIGERWALT, ${ }^{1}$ G. R. FANNING, ${ }^{3}$ \\ ELISABETH AGERON, ${ }^{2}$ AND CONRADINE F. RIDDLE ${ }^{4}$ \\ Meningitis and Special Pathogens Branch, Division of Bacterial and Mycotic Diseases, ${ }^{1}$ and \\ Nosocomial Infections Laboratory Branch, Hospital Infections Program, ${ }^{4}$ National Center for Infectious \\ Diseases, Centers for Disease Control and Prevention, Atlanta, Georgia 30333; Unité des Entérobactéries, \\ Institut National de la Recherche Scientifique Unité 199, Institut Pasteur, 75724 Paris, Cedex 15, France ${ }^{2}$; \\ and Division of Biochemistry, Walter Reed Army Institute of Research, Washington, D. C. 20307-5100
}

\begin{abstract}
DNA relatedness studies (hydroxyapatite method) were done on 112 strains of citrobacteria. By using the recommended definition of a genomospecies 11 genomospecies were identified in the genus Citrobacter. These genomospecies were separable by their biochemical profiles. Citrobacter koseri (Citrobacter diversus) and Citrobacter amalonaticus proved to be homogeneous species, as previously described. $C$. amalonaticus biogroup 1, as described by Farmer et al. (J. Clin. Microbiol. 21:46-76, 1985), was shown to be a separate homogeneous species, which was named Citrobacter farmeri sp. nov. The Citrobacter freundii complex was quite heterogeneous. $C$. freundii sensu stricto, as represented by the type strain, contained only 9 of 66 strains in this complex. The remaining 57 strains were members of seven genomospecies. Genomospecies 5, containing 21 strains, was named Citrobacter youngae sp. nov. Genomospecies 6, containing 15 strains, was named Citrobacter braakii sp. nov. Genomospecies 7 and 8, each containing six strains, were named Citrobacter werkmanii sp. nov. and Citrobacter sedlakii sp. nov., respectively. Genomospecies 9, 10, and 11, each containing three strains, were not named.
\end{abstract}

The genus Citrobacter and the species Citrobacter freundii were designated in 1932 by Werkman and Gillen (13). Citrobacter koseri $(8,9)$ (Citrobacter diversus [4], Levinea malonatica [14]) and Citrobacter amalonaticus (5) (Levinea amalonatica [14]) are the other previously recognized Citrobacter species. Strains of the latter two species were initially identified as indole-positive, $\mathrm{H}_{2} \mathrm{~S}$-negative biogroups of $C$. freundii. C. koseri also differs from $C$. freundii by its failure to grow in medium containing $\mathrm{KCN}$ and from both $C$. freundii and $C$. amalonaticus by its ability to utilize malonate and to produce acid from D-adonitol.

It has long been evident that a significant number of Citrobacter isolates from human clinical specimens do not exhibit the biochemical characteristics typical of these three previously described species (7). DNA relatedness studies have also revealed substantial heterogeneity within strains identified as $C$. freundii (3). Farmer et al. created the name C. amalonaticus biogroup 1 for strains, usually isolated from human feces, that differed from $C$. amalonaticus by their ability to usually ferment melibiose, $\alpha$-methyl-D-glucoside, raffinose, and sucrose and their inability to utilize citrate (7).

The purpose of this study was to determine, by calculating levels of DNA relatedness, whether biochemically atypical Citrobacter strains in the culture collections of the Centers for Disease Control and Prevention (CDC) and the Institut Pasteur represent biotypes of previously described species or additional, undescribed species. Biochemical characteristics of the previously described species and each new

\footnotetext{
* Corresponding author.
}

genomospecies detected on the basis of DNA relatedness levels were reexamined. (Genomospecies is a word that we have coined to use instead of genospecies. A genomospecies is a species defined by DNA relatedness [12]. Genomic species is another synonym for genomospecies and genospecies. The term genomovar was used by Rossello et al. "to denote genomic groups of a nomenspecies" [10a]; "var" is traditionally used for differentiation below the species level, and we therefore prefer the term genomospecies or genomic species.) The traditional diagnostic laboratory tests were augmented by a battery of carbon source utilization tests to allow biochemical identification of each species and differentiation from all other species in the genus.

Eleven genomospecies were identified. Genomospecies 1 through 3 corresponded to $C$. freundii, $C$. koseri, and $C$. amalonaticus, respectively. Genomospecies 4, which corresponded to $C$. amalonaticus biogroup 1, was named Citrobacter farmeri sp. nov. Genomospecies 5 through 8 were named Citrobacter youngae sp. nov., Citrobacter braakii sp. nov., Citrobacter werkmanii sp. nov., and Citrobacter sedlakii sp. nov., respectively. Genomospecies 9 through 11, each containing three strains, were not named.

\section{MATERIALS AND METHODS}

Strains. The strains used in this study are listed in Table 1. All strains were originally sent for identification to diagnostic reference laboratories at the CDC or the Institut Pasteur. For consistency, CDC strain numbers are used in the Results and Discussion. The following type strains were used: $C$. amalonaticus (L. amalonatica) CDC 9020-77 (= ATCC 


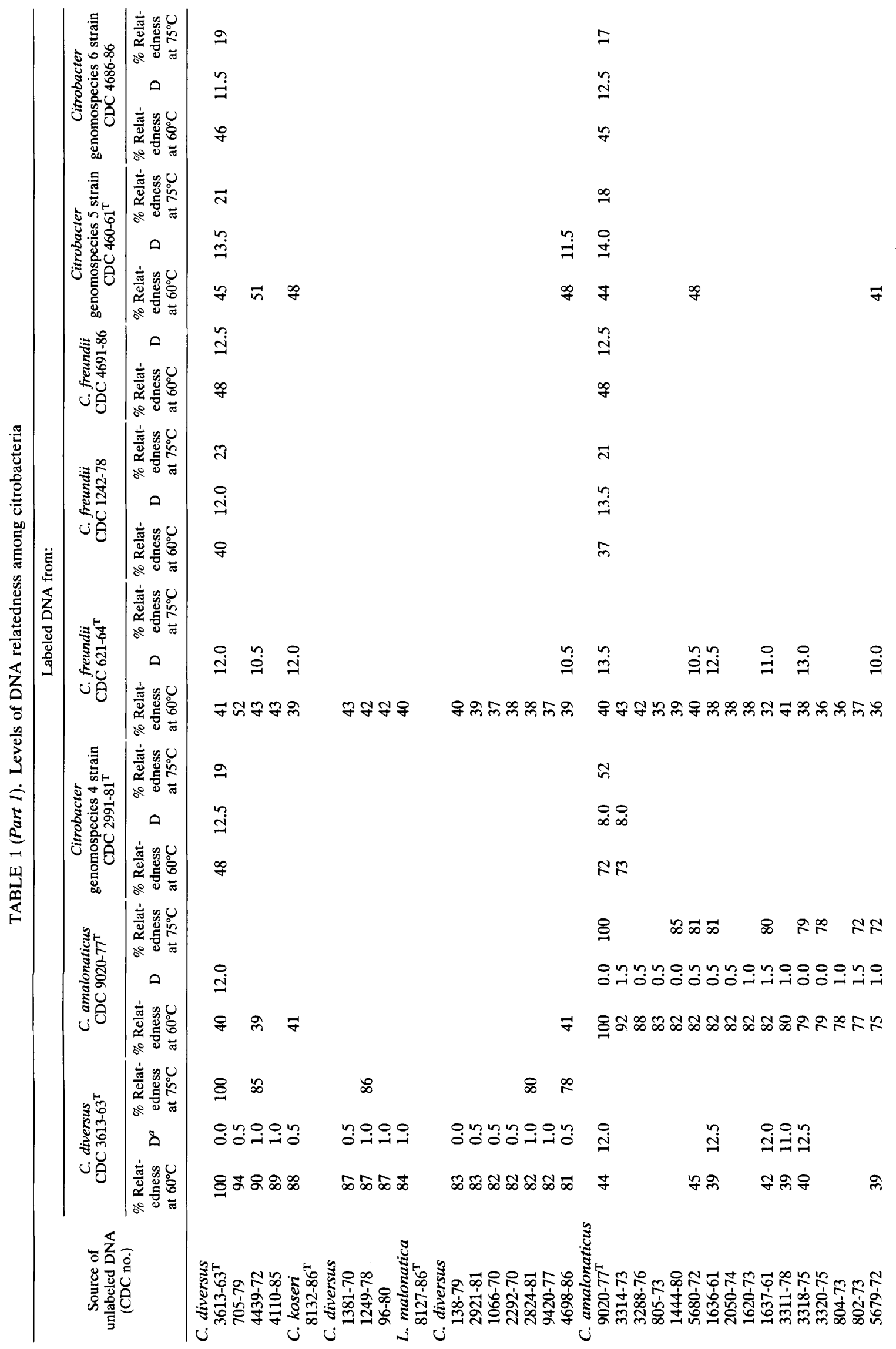




\begin{tabular}{|c|c|c|c|c|}
\hline \pm & $\stackrel{\infty}{n}$ & $\vec{\sigma}$ & 8 & in \\
\hline I & $\tilde{n}$ & $\ddot{i}$ & $\ddot{n}$ & nn \\
\hline & $\sigma$ & 8 & 3 & 65 \\
\hline
\end{tabular}

\begin{tabular}{|c|c|c|c|c|c|}
\hline & & in & 乎守 & 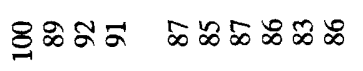 & 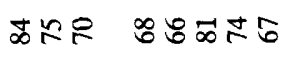 \\
\hline$n$ & & $n$ & no: & 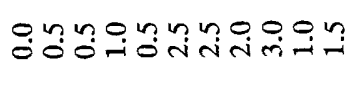 & 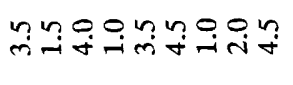 \\
\hline$q$ & $\forall$ & $F$ & $\infty \approx 330$ & 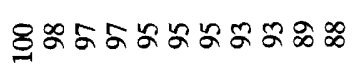 & 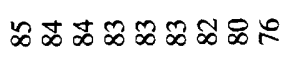 \\
\hline 0 & & $\dot{0}$ & $\ddot{m} \stackrel{+}{\dot{r}}$ & $n$ & \\
\hline N & & 임 & $\stackrel{\infty}{\sim}$ & 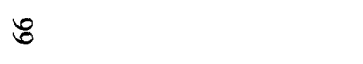 & \\
\hline
\end{tabular}

2

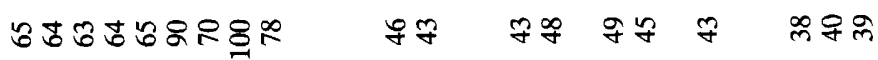

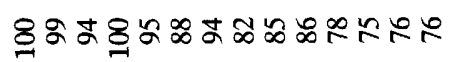

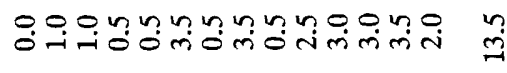

$\stackrel{\circ}{\operatorname{m}}$

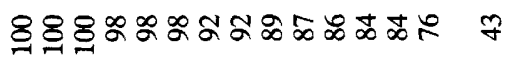

m

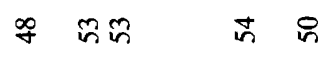

๑ู

?

iㅗㄹ

$\stackrel{\circ}{2}$

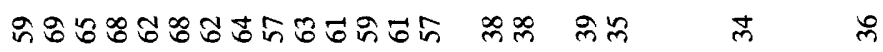

$\stackrel{n}{=}$

$\stackrel{\text { త్ }}{ }$

$\stackrel{\text { บิ }}{\text { บิ }}$

$\vec{\gamma}$

q

ఫ

$5 \quad \% \quad F$

q
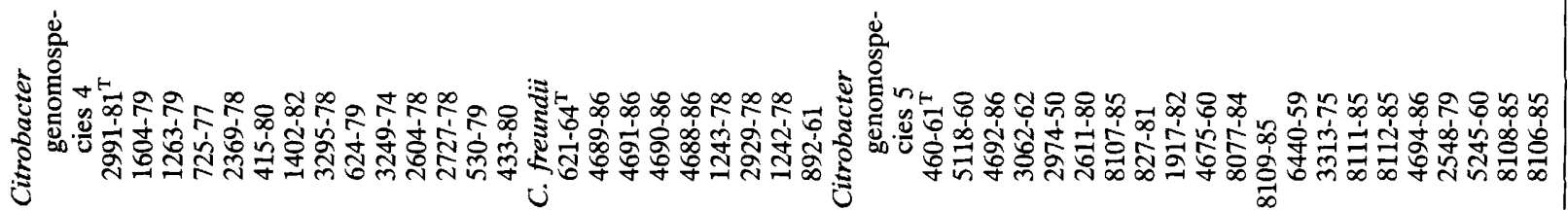


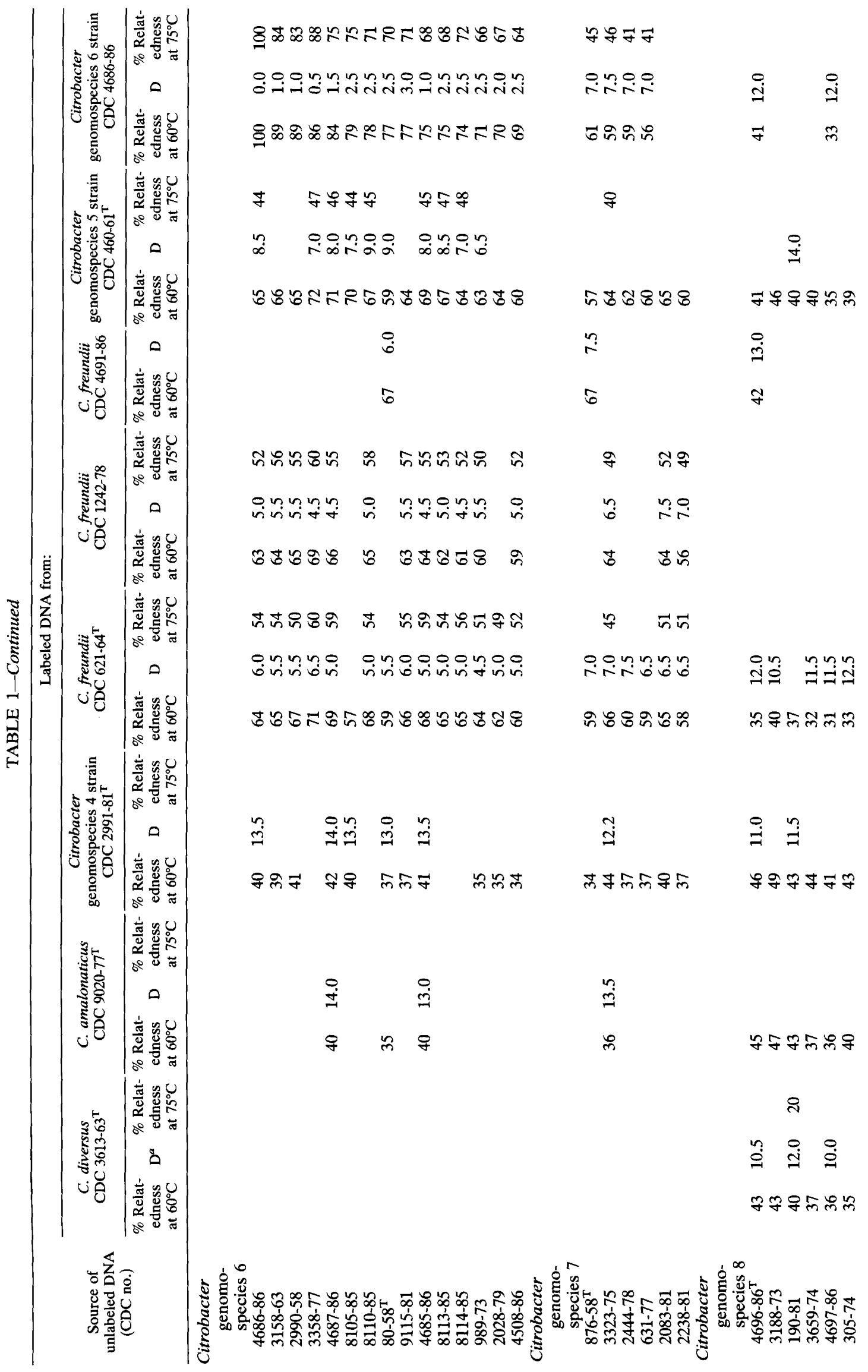




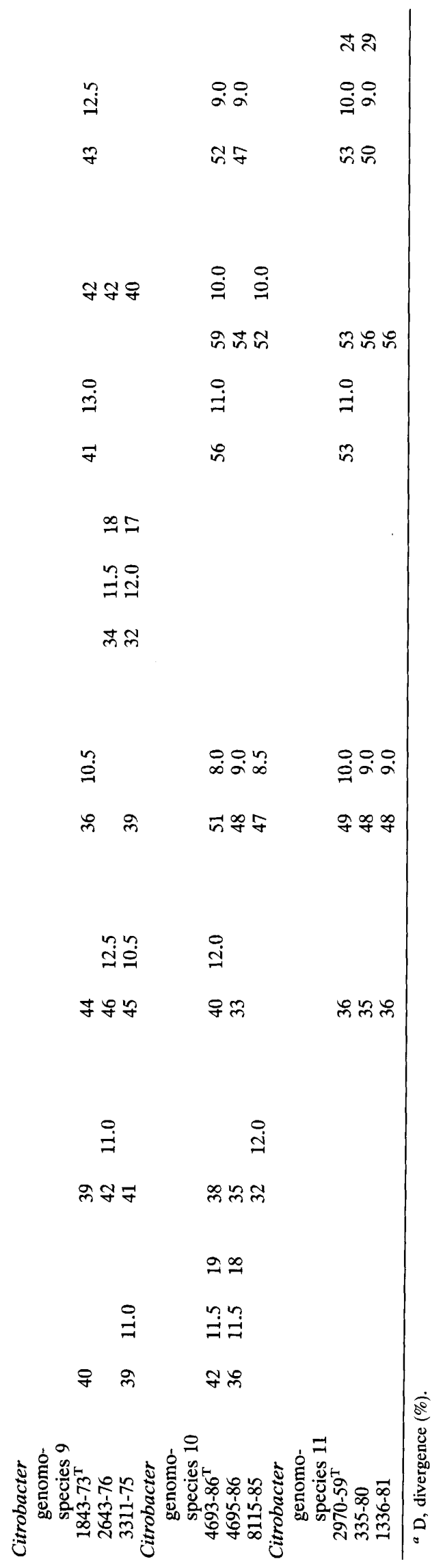

25407), C. diversus (a synonym of $C$. koseri) CDC 3613-63 (= ATCC 27156), L. malonatica (a synonym of $C$. koseri) CDC 8127-86 (= ATCC 25408), C. koseri CDC 8132-86 (= ATCC 27028), and $C$. freundii CDC 621-64 (= ATCC 8090). The following strains were obtained from the Institut Pasteur: 13-61 (= CDC 4692-86), 9-73 (= CDC 4697-86), 1-75 ${ }^{\mathrm{T}}$ (= $\left.\mathrm{CDC}_{4696-86^{\mathrm{T}}}\right)(\mathrm{T}=$ type strain $), 7-76(=\mathrm{CDC} 4698-86), 1-83$ (= CDC 4687-86), 72-84 (= CDC 4689-86), 80-84 (= CDC 4691-86), 84-84 (= CDC 4688-86), 92-84 (= CDC 4694-86), 102-84 (= CDC 4690-86), 1-85 (= CDC 4685-86), 3-85 (= CDC 4693-86), 5-84 (= CDC 4695-86), and 37-85 (= CDC 4686-86). The following strains were previously studied by Crosa et al. (3) (the designations used in the study of Crosa et al. are given in parentheses): CDC 2974-50 (= Bethesda 7), CDC 4675-65 (= 4675-60 sic), CDC 8105-85 (= P11c), CDC 8106-85 (= Bethesda 1A), CDC 8107-85 (= Bethesda 2A), CDC 8108-85 (= Bethesda 3A), CDC 8109-85 (= Bethesda 4A), CDC 8110-85 (= Bethesda 6), CDC 8111-85 (= Bethesda 8A), CDC 8112-85 (= Bethesda 9A), CDC 8113-85 (= Bethesda 29A), CDC 8114-85 (= 3796), and CDC 8115-85 (= H310a).

Biochemical tests. The methods used for biochemical testing at the CDC (Table 2 ) have been described previously $(6$, 10). All test preparations were incubated at $36 \pm 1^{\circ} \mathrm{C}$ for 7 days unless otherwise specified. Carbon source utilization tests were done at the Institut Pasteur by using Biotype strips (BioMérieux, La Balme les Grottes, France) that contained 99 pure carbon sources. The strips were inoculated by using Biotype medium 1 according to the manufacturer's instructions. The carbon sources used are shown in Table 3. Preparations were incubated at $30^{\circ} \mathrm{C}$ for 4 days.

DNA hybridization. To obtain cells for DNA extraction, Citrobacter strains were grown in brain heart infusion broth at $36 \pm 11^{\circ} \mathrm{C}$ with shaking until they reached the late logarithmic phase. The methods used for extraction and purification of DNA and the hydroxyapatite hybridization method for determining levels of DNA relatedness have been described previously (2). DNAs were labeled enzymatically in vitro with $\left[{ }^{32} \mathrm{P}\right] \mathrm{dCTP}$ by using a nick translation reagent kit (Bethesda Research Laboratories, Inc., Gaithersburg, Md.) as directed by the manufacturer.

\section{RESULTS}

DNA relatedness studies were done on 112 strains identified as members of the genus Citrobacter. These strains were categorized into 11 genomospecies (Table 1). Genomospecies 2 contained 16 strains, all of which had been previously identified biochemically as $C$. koseri. Included in genomospecies 2 were the type strains of $C$. diversus, $C$. koseri, and $L$. malonatica, all of which are subjective synonyms. Genomospecies 3 contained 16 strains that had been previously identified as $C$. amalonaticus; it included the type strain of $C$. amalonaticus, which is also the type strain of $L$. amalonatica. Genomospecies 4 contained all 14 strains biochemically identified as $C$. amalonaticus biogroup 1 .

Genomospecies 1 contained the type strain of $C$. freundii, but included only 9 of 66 strains previously identified biochemically as $C$. freundii or as closest to $C$. freundii. The remaining $57 \mathrm{C}$. freundii-like strains were members of seven genomospecies; 21 strains were in genomospecies 5,15 strains were in genomospecies 6, 6 strains each were in genomospecies 7 and 8 , and 3 strains each were in genomospecies 9,10 , and 11 .

Conventional biochemical reactions for each genomospecies are given in Table 2 . It is possible to identify each 


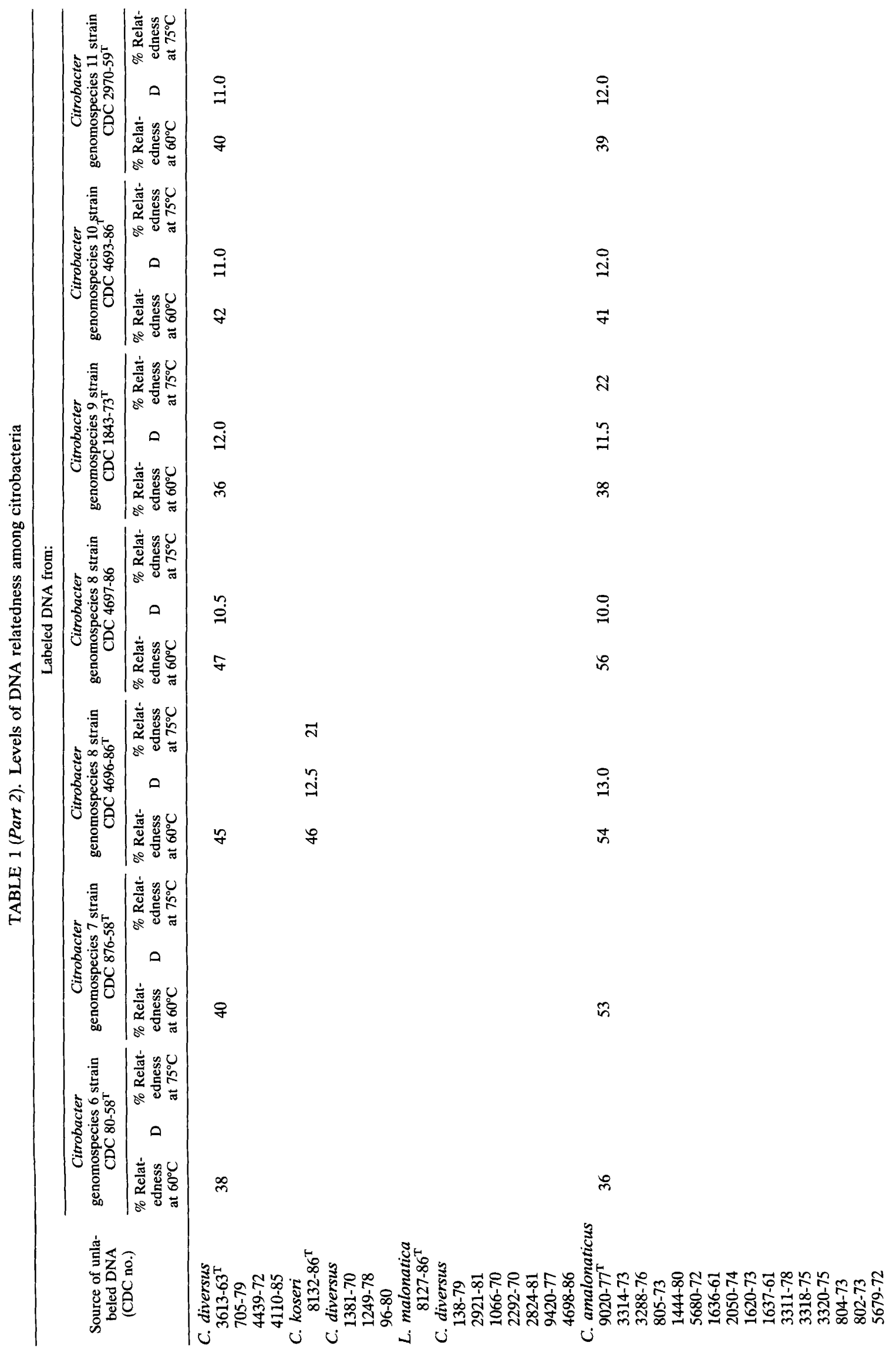


$\stackrel{P}{=}$

से

$\stackrel{n}{3}$

通

$\stackrel{n}{=}$

$\infty$

?

ร

$\stackrel{i}{\text { I }}$

\&

q

$m$

$\stackrel{n}{2}$

m

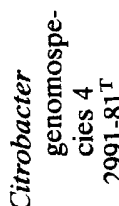

i

8

$\stackrel{\circ}{\infty}$

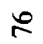

$\stackrel{\infty}{+}$

$\ddot{\infty} \quad \stackrel{n}{\infty}$

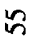

g

$\because$ 管

满 i

$\tilde{y}$

षे

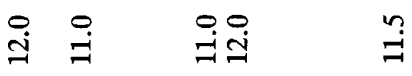

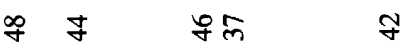

in

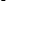




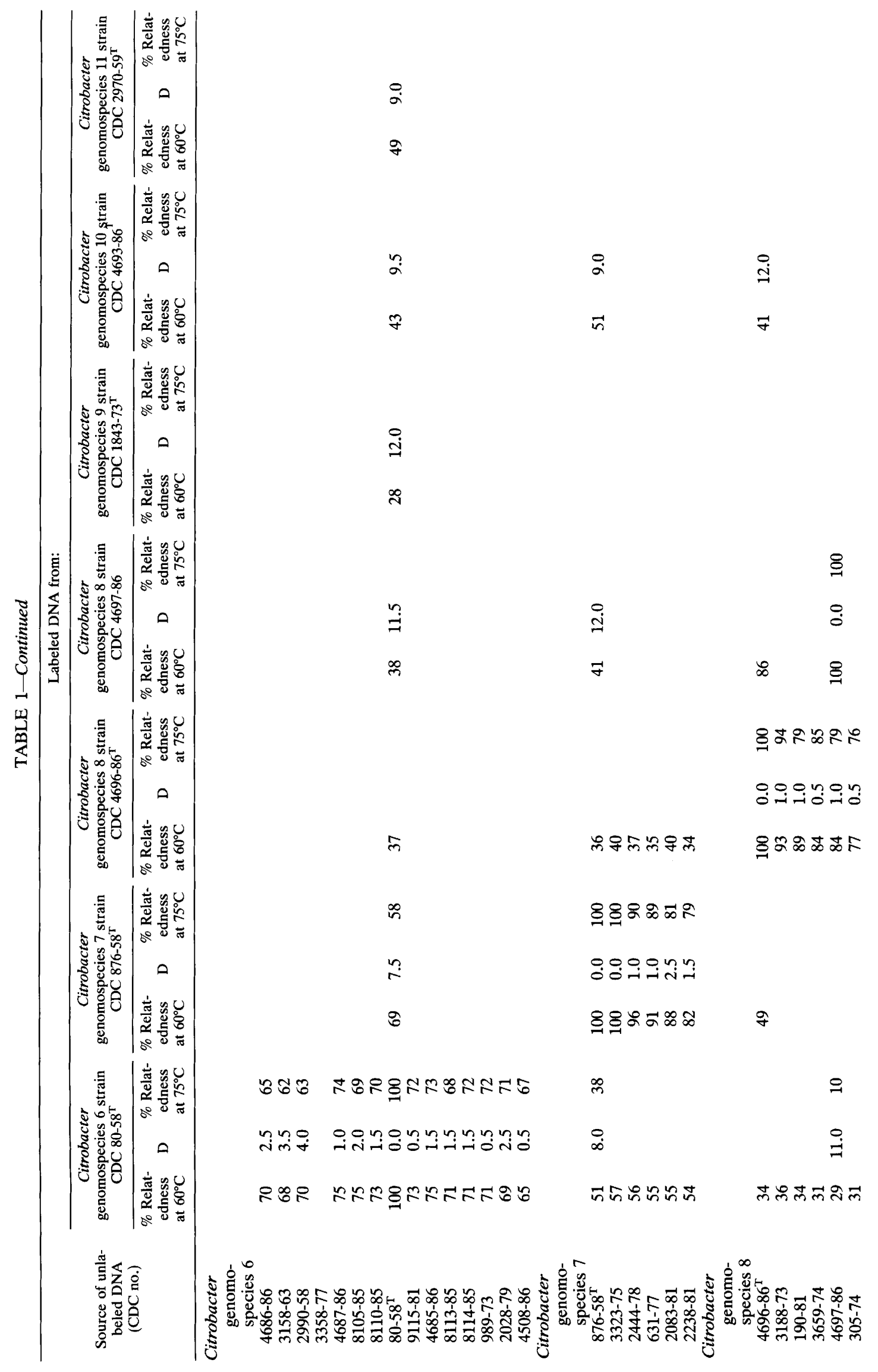




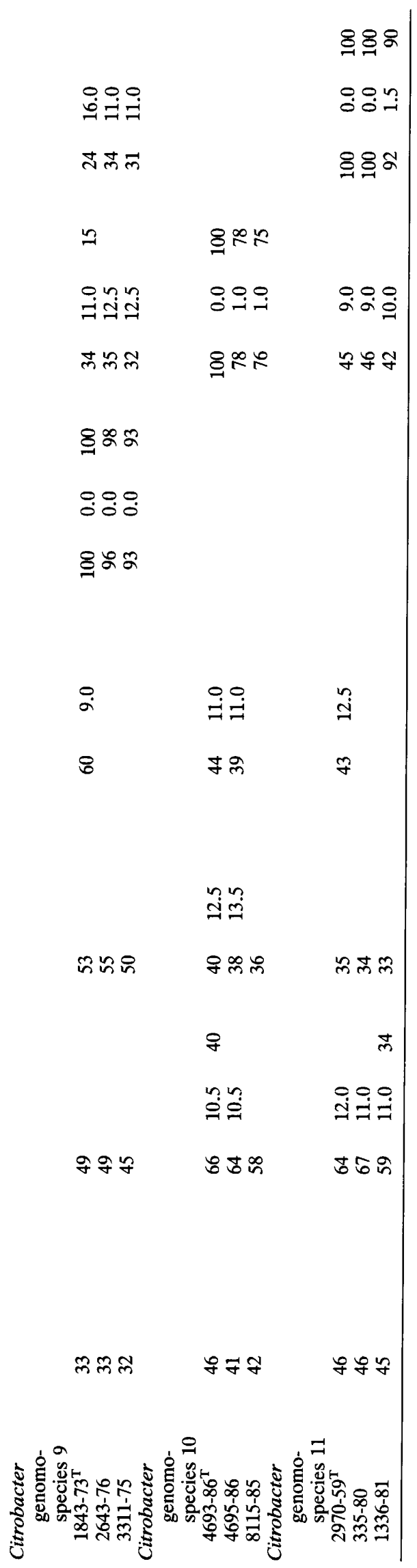

genomospecies on the basis of these commonly employed tests. Results of carbon source utilization tests, done on the same strains, are given in Table 3 . All of the genomospecies can be differentiated on the basis of carbon source utilization reactions.

Table 4 shows the conventional biochemical and carbon source utilization test results that are most useful for identifying the Citrobacter genomospecies. Since genomospecies 2 (C. koseri) is the only Citrobacter species that can produce acid from adonitol and D-arabitol, it was omitted from Table 4 for simplicity. When only conventional biochemical tests are used, two or more tests are used for differentiating between all pairs of genomospecies except the following pairs: genomospecies 1 and 10 (only the malonate test is used), genomospecies 6 and 8 (only the malonate test is used), and genomospecies 6 and 11 (only the ornithine decarboxylase test is used).

All genomospecies can be differentiated by at least two carbon source utilization tests.

\section{DISCUSSION}

A genomospecies has been defined as a group of strains whose DNAs are at least $70 \%$ interrelated, with $5 \%$ or less divergence in the related sequences (12). When this definition was used, DNA relatedness studies identified 11 genomospecies in the genus Citrobacter. The results obtained confirmed the hypothesis of Farmer et al. that $C$. amalonaticus biogroup 1 is a fourth species in the genus Citrobacter (7). The biochemical and genetic heterogeneity previously observed in strains identified as $C$. freundii $(3,7)$ was confirmed and extended. In fact, other than the strains identified as $C$. amalonaticus biogroup 1, strains previously identified as $C$. freundii or Citrobacter species were shown to belong to seven previously undescribed DNA hybridization groups or genomospecies.

Each of the 11 genomospecies of the genus Citrobacter can be identified by conventional biochemical tests (Tables 2 and 4) and by carbon source utilization tests (Tables 3 and 4). A combination of conventional and carbon source utilization tests provides a very firm basis for identification of all citrobacteria.

A total of 112 strains were included in this study. Sixteen of these were $C$. koseri (genomospecies 2) strains, 16 were C. amalonaticus (genomospecies 3 ) strains, and 14 were $C$. amalonaticus biogroup 1 (genomospecies 4) strains. Of the remaining 66 strains, only 9 were members of $C$. freundii (genomospecies 1) as defined by the type strain of this species, CDC 621-64. The majority of the strains were in genomospecies 5 (21 strains) and 6 (15 strains); genomospecies 7 and 8 each contained 6 strains, and genomospecies 9 , 10 , and 11 each contained 3 strains.

It seems likely that $C$. freundii is not the most frequently isolated Citrobacter species, although to verify this it will be necessary to reidentify the strains in our culture collection on the basis of the biochemical characteristics determined in this study. Of course, especially for those genomospecies with small numbers of strains, it will be necessary to verify that their biochemical profiles are definitive.

On the basis of the extremely limited clinical data received with the strains studied, it is impossible to estimate the clinical significance of these organisms (Table 5). Nonetheless, the small amount of available information suggests the possibility of clinical differences among citrobacteria. $C$. koseri isolates were obtained from men $(61 \%)$ more often than from women, whereas exactly the opposite prevalence 
TABLE 2. Conventional biochemical reactions for Citrobacter genomospecies ${ }^{a}$

\begin{tabular}{|c|c|c|c|c|c|c|c|c|c|c|c|}
\hline \multirow[b]{2}{*}{ Test } & \multicolumn{11}{|c|}{$\%$ of positive strains } \\
\hline & $\begin{array}{l}\text { Genomo- } \\
\text { species } 2\end{array}$ & $\begin{array}{l}\text { Genomo- } \\
\text { species } 3\end{array}$ & $\begin{array}{l}\text { Genomo- } \\
\text { species } 4\end{array}$ & $\begin{array}{l}\text { Genomo- } \\
\text { species } 1\end{array}$ & $\begin{array}{l}\text { Genomo- } \\
\text { species } 5\end{array}$ & $\begin{array}{l}\text { Genomo- } \\
\text { species } 6\end{array}$ & $\begin{array}{l}\text { Genomo- } \\
\text { species } 7\end{array}$ & $\begin{array}{l}\text { Genomo- } \\
\text { species } 8\end{array}$ & $\begin{array}{l}\text { Genomo- } \\
\text { species } 9\end{array}$ & $\begin{array}{l}\text { Genomo- } \\
\text { species } 10\end{array}$ & $\begin{array}{l}\text { Genomo- } \\
\text { species } 11\end{array}$ \\
\hline Indole & 94 & 100 & 100 & 38 & 14 & 33 & 0 & 100 & 0 & 0 & 100 \\
\hline Citrate (Simmons) & 100 & 100 & $7(86)$ & 88 & $76(95)$ & $87(100)$ & 100 & $83(100)$ & 0 & $33(100)$ & 100 \\
\hline $\begin{array}{l}\mathrm{H}_{2} \mathrm{~S} \text { produced on triple } \\
\text { sugar-iron agar }\end{array}$ & 0 & 13 & 0 & $75(88)$ & $67(81)$ & 60 & 100 & 0 & 0 & 67 & 67 \\
\hline Urease & $56(69)$ & 81 & 36 & $38(50)$ & 76 & $47(67)$ & 83 & 100 & 100 & 0 & $67(100)$ \\
\hline Arginine & $88(94)$ & $81(100)$ & 100 & $75(100)$ & $52(90)$ & $67(100)$ & 100 & 100 & 0 & $33(100)$ & $67(100)$ \\
\hline Ornithine & $94(100)$ & $94(100)$ & 100 & 0 & 5 & 93 & 0 & 100 & 100 & 0 & 0 \\
\hline Motility & 94 & $94(100)$ & 100 & 100 & 95 & 87 & 100 & 100 & 0 & 67 & 100 \\
\hline $\mathrm{KCN}$ & $0(6)$ & $94(100)$ & 100 & $88(100)$ & $95(100)$ & 100 & 100 & 100 & 33 & 100 & 100 \\
\hline Malonate & 94 & 13 & 0 & 13 & 5 & 0 & 100 & 100 & 100 & 100 & 0 \\
\hline D-Glucose (gas) & 100 & 94 & 100 & 100 & 76 & 93 & 100 & 100 & 100 & 100 & 100 \\
\hline \multicolumn{12}{|l|}{ Acid produced from: } \\
\hline Lactose & $75(94)$ & $38(88)$ & $21(100)$ & $88(100)$ & $24(90)$ & $80(87)$ & $17(100)$ & 100 & 100 & 67 & $67(100)$ \\
\hline Sucrose & 44 & 13 & 100 & 100 & 19 & 7 & 0 & 0 & 0 & 33 & 33 \\
\hline Dulcitol & 38 & 0 & 0 & 13 & 86 & 33 & 0 & 100 & 0 & 0 & 100 \\
\hline Salicin & $19(94)$ & $31(94)$ & $0(93)$ & $0(13)$ & 10 & $0(7)$ & 0 & $17(50)$ & $0(100)$ & $0(67)$ & $0(67)$ \\
\hline Adonitol & 94 & 0 & 0 & 0 & 0 & 0 & 0 & 0 & 0 & 0 & 0 \\
\hline Raffinose & 0 & 0 & 100 & $50(100)$ & 10 & $7(13)$ & 0 & 0 & 0 & 0 & 33 \\
\hline Cellobiose & 94 & 100 & 100 & $25(75)$ & $43(100)$ & $73(93)$ & $20(100)$ & 100 & 100 & 67 & 100 \\
\hline$\alpha-\mathrm{CH}_{3}$-glucoside & $40(93)$ & $14(21)$ & $92(100)$ & $0(25)$ & $0(5)$ & $29(43)$ & 0 & 0 & 0 & 0 & 0 \\
\hline Esculin & $0(33)$ & $0(29)$ & $0(54)$ & 0 & 5 & 0 & 0 & $17(50)$ & $0(33)$ & $0(33)$ & $0(100)$ \\
\hline Melibiose & 0 & 0 & 100 & 100 & 5 & $78(100)$ & 0 & 100 & 0 & 67 & $33(100)$ \\
\hline D-Arabitol & 100 & 0 & 0 & 0 & 0 & 0 & 0 & 0 & 0 & 0 & 0 \\
\hline Glycerol & 100 & $25(31)$ & 85 & 100 & $90(100)$ & 86 & 100 & 67 & 0 & $67(100)$ & 100 \\
\hline Acetate & $86(93)$ & $93(100)$ & $77(100)$ & $50(75)$ & $67(76)$ & $50(92)$ & $80(100)$ & 83 & $33(67)$ & $0(33)$ & $33(100)$ \\
\hline $\mathrm{NO}_{3}$ reduced to $\mathrm{NO}_{2}$ & 100 & 93 & 100 & 100 & 86 & 100 & 100 & 100 & 100 & 100 & 100 \\
\hline $\mathrm{ONPG}^{b}$ & 100 & 100 & 100 & 100 & 95 & 85 & 100 & 100 & 100 & $67(100)$ & 100 \\
\hline
\end{tabular}

${ }^{a}$ Most preparations were incubated at $36 \pm 11^{\circ} \mathrm{C}$; the exceptions were the gelatin liquefaction preparation $\left(22^{\circ} \mathrm{C}\right)$ and the DNase preparation $\left(25^{\circ} \mathrm{C}\right)$. Most results were read after 7 days of incubation; the methyl red and Voges-Proskauer results were read after 2 days. Results are expressed as percentages of positive strains within $48 \mathrm{~h}$; the values in parentheses are the percentages of strains which gave delayed-positive reactions. The following tests, except as noted, were positive for all strains tested: methyl red, acid production from D-glucose, acid production from D-mannitol, acid production from D-sorbitol (one genomospecies 2 strain was negative), acid production from L-arabinose, acid production from L-rhamnose, acid production from maltose (one genomospecies 3 strain was delayed positive and one genomospecies 5 strain was negative), acid production from D-xylose (one genomospecies 1 strain was delayed positive), acid production from trehalose, acid production from mucate (one genomospecies 10 strain was delayed positive), acid production from tartrate (one genomospecies 1 strain and one genomospecies 6 strain were negative), and acid production from mannose. The following tests, except as noted, were negative for all strains tested: phenylalanine deaminase, lysine decarboxylase (one genomospecies 6 strain was positive), gelatin liquefaction, acid production from myo-inositol (one genomospecies 1 strain was delayed positive), acid production from erythritol, lipase, DNase, oxidase, and pigment.

${ }^{b}$ ONPG, $o$-nitrophenyl- $\beta$-D-galactopyranoside.

of isolation (61\% from women) was seen in C. amalonaticus and $C$. amalonaticus biogroup 1 . Most of the Citrobacter genomospecies were isolated from nonhuman as well as human sources; however, genomospecies 9 was isolated only from animals. Human isolates of all genomospecies except $C$. koseri were obtained predominantly from stools; C. koseri was most often isolated from urine and cerebrospinal fluid.

It is clear that clinical data are needed on all of the genomospecies formerly grouped in $C$. freundii. We hope that the delineation of 11 genomospecies in the genus Citrobacter, the means to identify these taxa biochemically (Tables 2 to 4 ), and the taxonomic proposals given below will aid in determining both the incidence and clinical significance of these organisms.

Description of Citrobacter farmeri sp. nov. Citrobacter farmeri (far'mer.i. N. L. gen. n. farmeri, to honor John J. Farmer III, an American microbiologist, who recognized and biochemically defined $C$. amalonaticus biogroup 1 and who has made many substantial contributions to the recognition and classification of new species and genera in the Enterobacteriaceae and other families [5-7]). Informally called $C$. amalonaticus biogroup 1 and Citrobacter genomospecies 4. Indole positive and citrate negative or delayed positive. Produces arginine dihydrolase and ornithine decarboxylase. Other biochemical reactions useful in differentiation are acid production from $\alpha-\mathrm{CH}_{3}$-D-glucoside, melibiose, raffinose, and sucrose and the ability to utilize benzoate, 4-hydroxybenzoate, maltitol, D-melibiose, 1-O- $\mathrm{CH}_{3}$ - $\alpha$-galactoside, palatinose, protocatechuate, $\mathrm{D}$-raffinose, and sucrose but not $m$-coumarate, dulcitol, and malonate as sole carbon sources. Additional reactions useful in differentiation are given in Table 4. Full biochemical reactions are shown in Tables 2 and 3.

Isolated from human stools, urine, wounds, and blood. Presumptively pathogenic. The type strain is CDC 2991-81 (= ATCC 51112), which was isolated from the stool of a 1 -year-old boy in New York.

Description of Citrobacter youngae sp. nov. Citrobacter youngae (young'ae. N. L. gen. n. youngae, to honor Viola M. Young, an American microbiologist, for her contributions to the genus Citrobacter, including the description of $C$. amalonaticus [L. amalonatica] [14]). Corresponds to Citrobacter genomospecies 5. Usually indole negative, delayed positive for citrate and arginine dihydrolase, and negative for ornithine decarboxylase. Other biochemical reactions useful in differentiation are acid production from dulcitol but not from melibiose and the ability to utilize 
TABLE 3. Carbon source utilization reactions of Citrobacter genomospecies

\begin{tabular}{|c|c|c|c|c|c|c|c|c|c|c|c|}
\hline \multirow{2}{*}{ Carbon source } & \multicolumn{11}{|c|}{$\%$ of positive strains ${ }^{a}$} \\
\hline & $\begin{array}{l}\text { Genomo- } \\
\text { species } 2\end{array}$ & $\begin{array}{l}\text { Genomo- } \\
\text { species } 3\end{array}$ & $\begin{array}{l}\text { Genomo- } \\
\text { species } 4\end{array}$ & $\begin{array}{l}\text { Genomo- } \\
\text { species } 1\end{array}$ & $\begin{array}{l}\text { Genomo- } \\
\text { species } 5\end{array}$ & $\begin{array}{l}\text { Genomo- } \\
\text { species } 6\end{array}$ & $\begin{array}{l}\text { Genomo- } \\
\text { species } 7\end{array}$ & $\begin{array}{l}\text { Genomo- } \\
\text { species } 8\end{array}$ & $\begin{array}{l}\text { Genomo- } \\
\text { species } 9\end{array}$ & $\begin{array}{l}\text { Genomo- } \\
\text { species } 10\end{array}$ & $\begin{array}{c}\text { Genomo- } \\
\text { species } 11\end{array}$ \\
\hline cis-Aconitate & 100 & $93(100)$ & $57(71)$ & 88 & $78(91)$ & $89(100)$ & 100 & 100 & 0 & $33(67)$ & $67(100)$ \\
\hline trans-Aconitate & $25(63)$ & 0 & 57 & $13(38)$ & 0 & 0 & 83 & $50(100)$ & 0 & 0 & 0 \\
\hline Adonitol & 100 & 0 & 0 & 0 & 0 & $0(6)$ & 0 & 0 & 0 & 0 & 0 \\
\hline D-Alanine & 100 & 100 & $71(85)$ & 100 & 100 & 100 & 100 & 100 & 100 & $67(100)$ & 100 \\
\hline 4-Aminobutyrate & $0(6)$ & $0(13)$ & $7(21)$ & $25(50)$ & $22(39)$ & $17(56)$ & $0(67)$ & 50 & 0 & 0 & $33(67)$ \\
\hline 5-Aminovalerate & $6(44)$ & $33(53)$ & $7(36)$ & $38(88)$ & $43(56)$ & 50 & 100 & $33(50)$ & 0 & 0 & $67(100)$ \\
\hline D-Arabitol & 100 & 0 & 0 & 0 & $0(4)$ & 0 & 0 & 0 & 0 & 0 & 0 \\
\hline Benzoate & 0 & 73 & 93 & 0 & 0 & 0 & 0 & 100 & 0 & 0 & 0 \\
\hline Caprate & $0(56)$ & $0(27)$ & $0(7)$ & 0 & $0(4)$ & 0 & 0 & $0(17)$ & 0 & 0 & 0 \\
\hline D-Cellobiose & 94 & 100 & 100 & 88 & $78(87)$ & $94(100)$ & $67(100)$ & 100 & 100 & 67 & 100 \\
\hline$m$-Coumarate & 0 & 0 & 0 & $88(100)$ & 96 & 100 & 100 & 67 & 0 & $33(67)$ & $0(67)$ \\
\hline Dulcitol & 44 & 0 & 0 & 13 & 87 & 33 & 0 & 100 & 0 & 0 & 100 \\
\hline Esculin & 0 & 0 & 0 & 0 & $0(9)$ & 6 & 0 & $17(50)$ & 0 & 0 & $0(33)$ \\
\hline Ethanolamine & $19(82)$ & $33(67)$ & 14 & $0(25)$ & $9(22)$ & 0 & $17(34)$ & $17(33)$ & 0 & 0 & $0(33)$ \\
\hline L-Fucose & 100 & 100 & 100 & 100 & $91(95)$ & 94 & 100 & 100 & 33 & 67 & 100 \\
\hline Gentiobiose & 88 & 100 & $93(100)$ & 88 & $52(78)$ & $89(100)$ & $67(100)$ & 100 & $0(33)$ & 67 & 100 \\
\hline Gentisate & 100 & 100 & $93(100)$ & 100 & 0 & $94(100)$ & 100 & 100 & 67 & 0 & 67 \\
\hline L-Glutamate & 100 & 100 & $86(100)$ & $75(88)$ & $83(92)$ & $94(100)$ & $83(100)$ & $83(100)$ & 67 & $0(33)$ & 100 \\
\hline Glycerol & 100 & 100 & 100 & 100 & 100 & 100 & 100 & 100 & 0 & 100 & 100 \\
\hline 3-Hydroxybenzoate & 100 & 100 & 100 & 100 & 0 & 100 & 100 & 100 & 100 & 0 & 67 \\
\hline 4-Hydro & 0 & 100 & 100 & 0 & 0 & 0 & 0 & 100 & 0 & 0 & 0 \\
\hline 3-Hydroxybutyrate & $6(12)$ & $20(33)$ & 7 & 100 & $74(87)$ & $44(66)$ & $67(100)$ & 100 & 0 & 0 & $33(67)$ \\
\hline myo-Inositol & 100 & 0 & 0 & 100 & 0 & 6 & 0 & 100 & 0 & 67 & 0 \\
\hline 2-Ketogluconate & 100 & 100 & 100 & 100 & 100 & 100 & 100 & 100 & $0(67)$ & 100 & 100 \\
\hline 5-Ketogluce & 100 & 100 & 100 & 100 & $96(100)$ & 100 & 50 & 0 & 0 & 100 & 100 \\
\hline 2-Ketoglutarate & 6 & $7(40)$ & $7(36)$ & $13(38)$ & $0(17)$ & $22(61)$ & $33(67)$ & $33(100)$ & 0 & $33(100)$ & $0(33)$ \\
\hline DL-Lactate & 100 & 100 & 100 & 100 & 100 & 100 & 100 & 100 & 33 & 100 & 100 \\
\hline Lactose & $56(87)$ & $20(87)$ & $50(86)$ & $88(100)$ & $22(44)$ & $78(84)$ & $17(34)$ & 100 & 100 & 67 & 33100 \\
\hline Lactulose & 0 & 0 & 7 & 88 & 0 & $67(78)$ & 17 & 100 & $0(33)$ & 67 & $33(100)$ \\
\hline D-Lyxose & 100 & 0 & $0(7)$ & $63(88)$ & $9(52)$ & $56(78)$ & $83(100)$ & $0(67)$ & 0 & 0 & 100 \\
\hline Malonate & $81(87)$ & 0 & 0 & 0 & 0 & 0 & $50(100)$ & $67(94)$ & $67(100)$ & 0 & 0 \\
\hline Maltitol & 100 & 7 & 93 & 25 & $0(4)$ & 44( & 0 & 0 & 0 & 0 & 0 \\
\hline D-Melibiose & 0 & 7 & 100 & 88 & 0 & $94(100)$ & 0 & 100 & 0 & 100 & $33(67)$ \\
\hline 1-O-CH$-\alpha$-galactoside & 0 & 0 & 100 & 88 & $0(22)$ & 100 & 0 & 100 & 0 & $67(100)$ & $0(100)$ \\
\hline 1-O-CH$-\beta$-galactoside & 100 & $7(34)$ & $14(43)$ & 100 & $65(87)$ & 83 & 100 & 100 & 100 & 67 & 100 \\
\hline 3-O-CH $-\mathrm{CH}_{3}-\mathrm{D}$-glucose & 13 & 87 & $86(100)$ & 63 & 0 & $94(100)$ & 100 & 100 & 0 & 0 & 67 \\
\hline $1-\mathrm{O}-\mathrm{CH}_{3}-\alpha-\mathrm{I}$ & $94(100)$ & 13 & $86(93)$ & 25 & 0 & $39(45)$ & 0 & 0 & 0 & 0 & 0 \\
\hline 1-O-CH $3-\beta$-D-glucoside & 100 & 100 & 100 & 100 & 100 & 100 & 100 & 100 & $0(33)$ & 100 & 100 \\
\hline Palatinose & 100 & 13 & 100 & 25 & 4 & 67 & 0 & 0 & 0 & 0 & 67 \\
\hline Phenylacetate & 0 & 0 & 0 & 25 & 0 & 0 & 0 & 0 & 0 & $0(33)$ & 0 \\
\hline propionate & 0 & 0 & 0 & 75 & 96 & 83 & 100 & 0 & 0 & $0(33)$ & $0(67)$ \\
\hline L-Prol & 100 & 87 & $57(71)$ & 100 & $87(91)$ & 100 & 100 & 100 & 100 & $33(100)$ & 100 \\
\hline Propionate & 88 & $80(87)$ & 86 & 88 & $78(87)$ & $72(78)$ & 100 & $83(100)$ & $67(100)$ & 0 & 100 \\
\hline Protocatechuate & 0 & 100 & 100 & 0 & 0 & 0 & 0 & 100 & 0 & 0 & 0 \\
\hline Putrescine & 0 & 0 & 0 & $50(75)$ & 0 & $39(61)$ & 67 & 0 & 100 & 0 & $0(67)$ \\
\hline D-F & 0 & 0 & 100 & $75(88)$ & 0 & $6(12)$ & 0 & 0 & 0 & 67 & 33 \\
\hline L-S & 0 & 87 & 100 & 100 & 100 & 6 & 83 & 0 & 0 & 0 & 100 \\
\hline Sucrose & 44 & 0 & 100 & 100 & $9(13)$ & 6 & 0 & 0 & 0 & 33 & 33 \\
\hline D-Tagatose & 0 & 0 & $36(43)$ & 13 & 4 & 0 & 0 & 0 & 0 & 0 & 0 \\
\hline D-Tartrate & 0 & 0 & 0 & 13 & 0 & 6 & 100 & 0 & 0 & 0 & 0 \\
\hline L-Tartrate & $19(75)$ & $33(73)$ & $36(65)$ & $0(63)$ & $22(74)$ & $17(67)$ & $67(84)$ & $17(50)$ & 100 & 0 & $33(67)$ \\
\hline artrate & 0 & $40(87)$ & $7(21)$ & 50 & $78(100)$ & $72(94)$ & 100 & $67(83)$ & 100 & 0 & $67(100)$ \\
\hline Tricarballylate & 0 & 93 & 100 & 100 & $4(17)$ & $89(95)$ & 100 & $83(100)$ & 100 & 0 & 100 \\
\hline D-Turanose & $6(31)$ & $0(13)$ & 36 & $0(13)$ & 0 & $11(17)$ & 0 & 0 & 0 & 0 & 0 \\
\hline & 88 & 0 & 0 & $75(88)$ & $74(87)$ & $72(100)$ & $67(100)$ & 0 & 0 & $0(33)$ & 100 \\
\hline Xylitol & $19(57)$ & 0 & 0 & 0 & 0 & 0 & 0 & 0 & 0 & 0 & 0 \\
\hline
\end{tabular}

${ }^{a}$ Percentages of strains which gave positive reactions within $48 \mathrm{~h}$. The numbers in parentheses are the percentages of strains which gave positive reactions within $96 \mathrm{~h}$. All strains, except as noted, utilized the following carbon sources within $48 \mathrm{~h}$ : $N$-acetyl-D-glucosamine, L-alanine, L-arabinose, L-aspartate (except one genomospecies 5 strain that was negative and one genomospecies 10 strain that was positive within $96 \mathrm{~h}$ ), citrate (except one genomospecies 4 strain that was positive within $96 \mathrm{~h}$ ), D-fructose, fumarate, D-galactose, D-galacturonate (except one genomospecies 10 strain), D-gluconate, D-glucosamine, D-glucose, D-glucuronate, DL-glycerate (except one genomospecies 2 strain), D-malate (except one genomospecies 4 strain and two genomospecies 10 strains that were positive within $96 \mathrm{~h}$ ), L-malate, maltose (except one genomospecies 5 strain), maltotriose (except one genomospecies 4 strain and one genomospecies 5 strain), D-mannitol, D-mannose, mucate (except one genomospecies 5 strain that was positive within $96 \mathrm{~h}$ ), L-rhamnose, D-ribose (except one genomospecies 5 strain), D-saccharate (except one genomospecies 5 strain and one genomospecies 10 strain), L-serine (except two genomospecies 4 strains), D-sorbitol, succinate, D-trehalose, and D-xylose (except two strains of genomospecies 1). All strains, except as noted, failed to utilize the following carbon sources within $96 \mathrm{~h}$ : L-arabitol, betaine, caprate, caprylate, i-erythritol, glutarate, histamine, L-histidine, HQ- $\beta$-glucuronide (except one genomospecies 6 strain), itaconate (except one genomospecies 7 strain that was positive within $96 \mathrm{~h}$ ), D-melezitose, quinate, trigonelline, tryptamine, and tryptophan. 


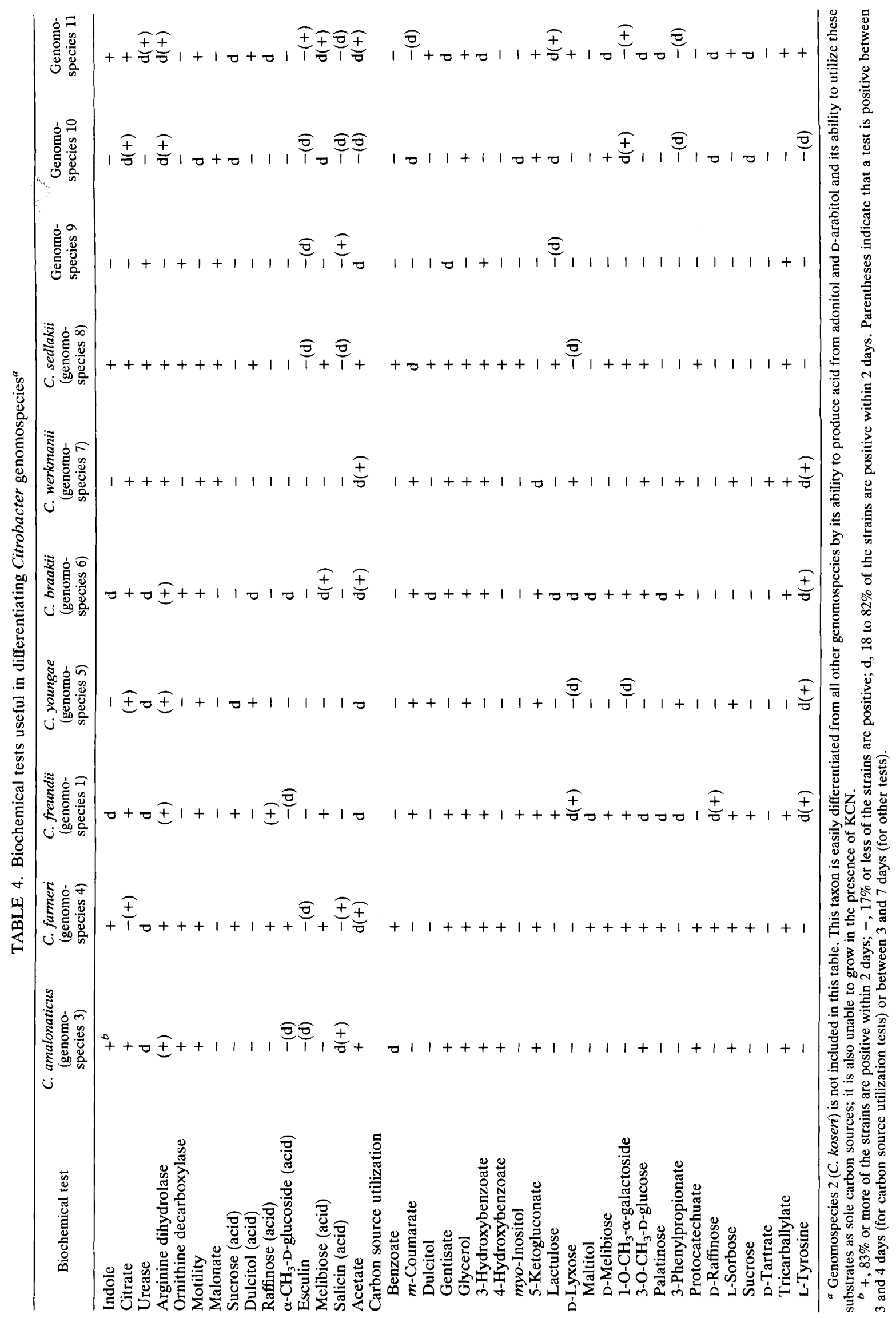


TABLE 5. Clinical information on Citrobacter isolates for which data were available

\begin{tabular}{|c|c|c|c|c|c|c|c|c|c|c|c|c|c|c|c|c|c|}
\hline \multirow[t]{2}{*}{ Taxon } & \multicolumn{2}{|c|}{$\begin{array}{l}\text { No. of strains } \\
\text { isolated from: }\end{array}$} & \multicolumn{7}{|c|}{$\begin{array}{l}\text { No. of strains } \\
\text { isolated from the } \\
\text { following human sources: }\end{array}$} & \multicolumn{3}{|c|}{$\begin{array}{l}\text { No. of strains } \\
\text { isolated from } \\
\text { the following } \\
\text { nonhuman sources: }\end{array}$} & \multicolumn{5}{|c|}{$\begin{array}{l}\text { No. of strains } \\
\text { isolated from humans } \\
\text { of the following ages: }\end{array}$} \\
\hline & Males & Females & Stools & Urine & $\begin{array}{l}\text { Cerebro- } \\
\text { spinal } \\
\text { fluid }\end{array}$ & Blood & Wounds & Sputum & Other & Animals & Food & Soil & $\begin{array}{l}<2 \\
\mathrm{yr}\end{array}$ & $\begin{array}{c}2-15 \\
\mathrm{yr}\end{array}$ & $\begin{array}{c}16-40 \\
\mathrm{yr}\end{array}$ & $\begin{array}{c}41-60 \\
\mathrm{yr}\end{array}$ & $\begin{array}{c}>60 \\
\mathrm{yr}\end{array}$ \\
\hline C. koseri & 29 & 19 & 4 & 18 & 14 & 6 & 3 & 7 & 2 & 1 & & & 10 & 1 & 1 & 3 & 16 \\
\hline C. amalonaticus & 18 & 28 & 32 & 3 & & 5 & 3 & 1 & & 1 & & & 7 & 1 & 3 & 5 & 8 \\
\hline $\begin{array}{l}\text { C. amalonaticus } \\
\text { biogroup } 1\end{array}$ & 16 & 25 & 25 & 6 & & 2 & 6 & & & & & 1 & 8 & 1 & 1 & 5 & 11 \\
\hline Genomospecies 1 & 1 & 1 & 5 & & & 1 & & & & 1 & 1 & & & & 1 & 1 & \\
\hline Genomospecies 5 & 3 & 3 & 11 & 1 & & & 2 & & & 3 & 1 & & 3 & 1 & & & \\
\hline Genomospecies 6 & 4 & 1 & 7 & & & & & & & 2 & & & & & 1 & 1 & 1 \\
\hline Genomospecies 7 & & 2 & 3 & & & 1 & & & & & & 1 & 1 & 1 & 1 & & \\
\hline Genomospecies 8 & 3 & 1 & 3 & & & 1 & 1 & & & & & & & & & & \\
\hline Genomospecies 9 & & & & & & & & & & 3 & & & & & & & \\
\hline Genomospecies 10 & & & 1 & & & & & & & & 1 & & & & & & \\
\hline Genomospecies 11 & & 2 & 1 & & & 1 & & & & & & & & & & 2 & \\
\hline
\end{tabular}

dulcitol, 3-phenylpropionate, and L-sorbose but not gentisate, 3-hydroxybenzoate, malonate, D-melibiose, 1-O- $\mathrm{CH}_{3}$ $\alpha$-galactoside, $3-\mathrm{O}-\mathrm{CH}_{3}$-D-glucose, and tricarballylate as sole carbon sources. Additional reactions useful in differentiation are given in Table 4. Full biochemical reactions are shown in Tables 2 and 3.

Isolated from human stools and blood and from animals and food. Presumptively pathogenic. The type strain is CDC 460-61 (= ATCC 29935), which was isolated from meat scraps in South Carolina.

Description of Citrobacter braakii sp. nov. Citrobacter braakii (braak'i.i. N. L. gen. n. braakii, to honor Hendrik R. Braak, a Dutch microbiologist, who worked on glycerol fermentation by enteric bacteria and isolated a glycerol fermenter that he called "Bacterium freundii" [1]). Corresponds to Citrobacter genomospecies 6. Production of indole is variable. Positive or delayed positive for citrate, arginine dihydrolase, and ornithine decarboxylase. Other biochemical reactions useful in differentiation are lack of acid production from salicin and sucrose and the ability to utilize $m$-coumarate, 1-O- $\mathrm{CH}_{3}$ - $\alpha$-galactoside, 3-phenylpropionate, and L-tyrosine (delayed) but not malonate and L-sorbose as sole carbon sources. Additional reactions useful in differentiation are given in Table 4 . Full biochemical reactions are shown in Tables 2 and 3.

Isolated from human stools, urine, and wounds and from animals and food. Presumptively pathogenic. The type strain is CDC 80-58 (= ATCC 51113), which was isolated from a snake in France.

Description of Citrobacter werkmanii sp. nov. Citrobacter werkmanii (werk'man.i.i. N. L. gen. n. werkmanii, to honor Chester H. Werkman, an American microbiologist, who studied the fermentative production of trimethylene glycol from glycerol and proposed the genus Citrobacter [13]). Corresponds to Citrobacter genomospecies 7. Negative for indole production and ornithine decarboxylase; citrate positive and positive for arginine dihydrolase. Other biochemical reactions useful for differentiation are lack of acid production from dulcitol, melibiose, and sucrose and the ability to utilize $m$-coumarate, D-lyxose, malonate, 3-phenylpropionate, L-sorbose, and D-tartrate but not dulcitol, 4-hydroxybenzoate, D-melibiose, and 1-O- $\mathrm{CH}_{3}-\alpha$-galactoside as sole carbon sources. Additional reactions useful in differen- tiation are given in Table 4. Full biochemical reactions are shown in Tables 2 and 3.

Isolated from human stools and urine and from food. Presumptively pathogenic. The type strain is CDC 876-58 (= ATCC 51114), which was isolated from a human stool in France.

Description of Citrobacter sedlakii sp. nov. Citrobacter sedlakii (sed.lak' i.i. N. L. gen. n. sedlakii, to honor Jiri Sedlak, a Czechoslovakian microbiologist, who developed a serotyping scheme for $C$. freundii [11]). Corresponds to Citrobacter genomospecies 8 . Positive for indole production, arginine dihydrolase, and ornithine decarboxylase. Delayed citrate positive. Other biochemical reactions useful for differentiation are production of acid from dulcitol and melibiose but not from sucrose and the ability to utilize benzoate, dulcitol, 4-hydroxybenzoate, myo-inositol, lactulose, malonate, 1-O- $\mathrm{CH}_{3}-\alpha$-galactoside, and protocatechuate but not 5-ketogluconate and L-sorbose as sole carbon sources. Additional reactions useful in differentiation are given in Table 4. Full biochemical reactions are shown in Tables 2 and 3.

Isolated from human stools, blood, and wounds. Presumptively pathogenic. The type strain is CDC 4696-86 (= ATCC 51115 ), which was isolated from a human stool in France.

The following genomospecies, although biochemically separable from each other and from all other citrobacteria, each contain only three strains. While it is not likely that additional strains will have markedly different biochemical characteristics, it is prudent to examine additional strains before naming these taxa.

Description of Citrobacter genomospecies 9. Citrobacter genomospecies 9 is negative for indole production, citrate, and arginine dihydrolase and is ornithine decarboxylase positive. Other biochemical reactions useful for differentiation are lack of motility, inability to produce acid from melibiose and sucrose, and ability to utilize malonate but not $m$-coumarate, glycerol, 5-ketogluconate, D-melibiose, 1-O$\mathrm{CH}_{3}-\alpha$-galactoside, and 3-O-CH$-\mathrm{CH}_{3}-\mathrm{D}$-glucose as sole carbon sources. Additional reactions useful for differentiation are given in Table 4. Full biochemical reactions are shown in Tables 2 and 3.

This organism has been isolated only from rodents and is presumptively pathogenic for these animals. The type strain 
is CDC 1843-73 (= ATCC 51116), which was isolated from a hamster in Connecticut.

Description of Citrobacter genomospecies 10. Citrobacter genomospecies 10 is negative for indole production and ornithine decarboxylase and delayed positive for citrate and arginine dihydrolase. Other biochemical reactions useful for differentiation are a negative urease reaction and the inability to utilize gentisate, 3-hydroxybenzoate, 3-O-CH$-\mathrm{C}$-glucose, L-sorbose, and tricarballylate as sole carbon sources.

This organism has been isolated from human stools and food; there is insufficient information to speculate on its clinical significance. The type strain is CDC 4693-86 (= ATCC 51117), which was isolated from a human stool in France.

Description of Citrobacter genomospecies 11. Citrobacter genomospecies 11 is indole and citrate positive, delayed positive for arginine dihydrolase, and ornithine decarboxylase negative. Other biochemical reactions useful for differentiation are acid production from dulcitol and the ability to utilize dulcitol, D-lyxose, 1-O- $\mathrm{CH}_{3}-\alpha$-galactoside (delayed), and L-tyrosine but not malonate and protocatechuate as sole carbon sources.

This organism has been isolated from human stools and blood; there is insufficient information to speculate on its clinical significance. The type strain is CDC 2970-59 (= ATCC 51118), which was isolated from an unknown source in Illinois.

\section{REFERENCES}

1. Braak, H. R. 1928. Onderzoekingen over Vergisting van Glycerine. Ph.D. thesis. University of Delft, Delft, The Netherlands.

2. Brenner, D. J., A. C. McWhorter, J. K. Leete-Knutson, and A. G. Steigerwalt. 1982. Escherichia vulneris: a new species of Enterobacteriaceae associated with human wounds. J. Clin. Microbiol. 15:1133-1140.

3. Crosa, J. H., A. G. Steigerwalt, G. R. Fanning, and D. J. Brenner. 1974. Polynucleotide sequence divergence in the genus Citrobacter. J. Gen. Microbiol. 83:271-282.

4. Ewing, W. H., and B. R. Davis. 1972. Biochemical characterization of Citrobacter diversus (Burkey) Werkman and Gillen and designation of the neotype strain. Int. J. Syst. Bacteriol. 22:12-18.

5. Farmer, J. J., III. 1981. The genus Citrobacter, p. 1140-1147. In M. P. Starr, H. Stolp, H. G. Trüper, A. Balows, and H. G. Schlegel (ed.), The prokaryotes, a handbook on habitats, isolation, and identification of bacteria. Springer-Verlag, New York.

6. Farmer, J. J., III, M. A. Asbury, F. W. Hickman, D. J. Brenner, and the Enterobacteriaceae Study Group. 1980. Enterobacter sakazakii: a new species of "Enterobacteriaceae" isolated from clinical specimens. Int. J. Syst. Bacteriol. 30:569-584.

7. Farmer, J. J., III, B. R. Davis, F. W. Hickman-Brenner, A. McWhorter, G. P. Huntley-Carter, M. A. Asbury, C. Riddle, H. G. Wathen-Grady, C. Elias, G. R. Fanning, A. G. Steigerwalt, C. M. O'Hara, G. K. Morris, P. B. Smith, and D. J. Brenner. 1985. Biochemical identification of new species and biogroups of Enterobacteriaceae isolated from clinical specimens. J. Clin. Microbiol. 21:46-76.

8. Frederiksen, W. 1970. Citrobacter koseri (n. sp.) a new species within the genus Citrobacter, with a comment on the taxonomic position of Citrobacter intermedium (Werkman and Gillen). Publ. Fac. Sci. Univ. J. E. Purkyne Brno K47:89-94.

9. Frederiksen, W. 1990. Correct names of the species Citrobacter koseri, Levinea malonatica, and Citrobacter diversus. Request for an opinion. Int. J. Syst. Bacteriol. 40:107-108.

10. Hickman, F. W., and J. J. Farmer III. 1978. Salmonella typhi: identification, antibiograms, serology, and bacteriophage typing. Am. J. Med. Technol. 44:1149-1159.

10a.Rossello, R., E. Garcia-Valdes, J. Lalucat, and J. Ursing. 1991. Genotypic and phenotypic diversity of Pseudomonas stutzeri. Syst. Appl. Microbiol. 14:150-157.

11. Sedlak, J. 1973. Present knowledge and aspects of Citrobacter. Curr. Top. Microbiol. Immunol. 62:41-59.

12. Wayne, L. G., D. J. Brenner, R. R. Colwell, P. A. D. Grimont, O. Kandler, M. I. Krichevsky, L. H. Moore, W. E. C. Moore, R. G. E. Murray, E. Stackebrandt, M. P. Starr, and H. G. Trüper. 1987. Report of the Ad Hoc Committee on Reconciliation of Approaches to Bacterial Systematics. Int. J. Syst. Bacteriol. 37:463-464.

13. Werkman, C. H., and G. F. Gillen. 1932. Bacteria producing trimethylene glycol. J. Bacteriol. 23:167-182.

14. Young, V. M., D. M. Kenton, B. J. Hobbs, and M. R. Moody. 1971. Levinea, a new genus of the family Enterobacteriaceae. Int. J. Syst. Bacteriol. 21:58-63. 